\title{
PENGARUH MODEL PEMBELAJARAN DAN JENIS PENILAIAN FORMATIF TERHADAP HASIL BELAJAR IPA SISWA SMPN
}

\author{
Ni Ketut Rapi \\ FMIPA Universitas Pendidikan Ganesha \\ e-mail: ketutrapi@yahoo.com
}

\begin{abstract}
Abstrak: Penelitian bertujuan untuk mendeskripsikan perbedaan hasil belajar IPA antara siswa yang mengikuti model pembelajaran inkuiri dan model pembelajaran konvensional, perbedaan hasil belajar IPA antara siswa yang mengikuti pembelajaran dengan PBK dan pembelajaran dengan penilaian konvensional, dan pengaruh interaksi antara model pembelajaran dan jenis penilaian formatif terhadap hasil belajar IPA. Penelitian ini menggunakan metode eksperimen semu. Populasi penelitian adalah siswa kelas VII SMPN Singaraja pada semester ganjil tahun ajaran 2015/2016 sebanyak 2398 siswa. Pengambilan sampel dilakukan dengan teknik multi stage, jumlah sampel 120 siswa. Instrumen pengumpulan data menggunakan tes bentuk objektif, dengan reliabilitas tes $=0,8770$, sedang analisis data menggunakan teknikanava dua jalur. Hasil penelitian ini menunjukkan: 1) terdapat perbedaan hasil belajar IPA antara siswa yang mengikuti model pembelajaran inkuiri dan model pembelajaran konvensional, 2) terdapat perbedaan hasil belajar IPA antara siswa yang diberi penilaian berbasis kelas dan yang diberi penilaian konvensional, terdapat pengaruh interaksi antara model pembelajaran dan jenis penilaian formatif terhadap hasil belajar IPA.
\end{abstract}

Kata kunci: model pembelajaran, jenis penilaian formatif, hasil belajar IPA

\section{THE INFLUENCE OF THE TEACHING MODEL AND \\ THE FORMATIVE EVALUATION TYPE ON THE STATE JUNIOR HIGH SCHOOL STUDENTS' SCIENCE LEARNING ACHIEVEMENT}

\begin{abstract}
The objectives of this study were 1) to describe the difference in the Science learning achievement between the students taught using the inquiry teaching model and those taught using the conventional teaching model; 2) to describe the difference in the Science learning achievement between the students joining the teaching with class-based evaluation and those joining the teaching with the conventional evaluation; and 3) to describe the influence of the interaction between the teaching model and the formative evaluation type on the Science learning achievement. This study used the quasi experimental design. The population was grade VII students of state junior high schools in Singaraja in the odd semester of 2015/2016 academic year consisting of 2,398 students. The sample consisting of 120 students was drawn using the multi-stage sampling technique. The data were collected using the objective test, with the reliability coefficient of 0.8770 . The data were analyzed using the two-way anova. The findings showed that: 1) there was a significant difference in the Science learning achievement between the students joining the inquiry teaching model and those joining the conventional teaching model; 2) there was a significant difference in the Science learning achievement between the students given the class-based evaluation and those given the conventional evaluation; and 3) there was an influence of the interaction between the teaching model and the formative evaluation type on the Science learning achievement.
\end{abstract}

Keywords: teaching model, formative evaluation type, Science learning achievement

\section{PENDAHULUAN}

Dewasa ini peradaban manusia sangat diwarnai oleh tingkat penguasaan ilmu pengetahuan dan teknologi. Pengembangan ilmu pengetahuan dan teknologi bersumber pada Matematika dan Ilmu Pengetahuan Alam (IPA). IPA memunyai 
peranan yang sangat penting dan strategis dalam pengembangan teknologi masa depan. Oleh karena itu, dalam memacu ilmu pengetahuan dan teknologi, proses pembelajaran IPA perlu mendapat perhatian yang lebih baik mulai dari tingkat SD sampai perguruan tinggi.

Buchori (2001) mengemukakann bahwa mendidik generasi muda menjadi spesialis di bidang sosial dan humaniora serta membiarkan mereka buta mengenai dunia sains dan teknologi merupakan suatu kesalahan besar. Dalam masyarakat yang dialiri arus kemajuan sains dan teknologi yang deras sekarang ini, manusia yang buta sains akan bingung, tidak mengerti apa yang terjadi disekitarnya dan juga tidak mengerti apa yang sedang terjadi dengan dirinya. Faure et al (1982) mengemukakan bahwa ide tentang belajar, bukan sebagai mimpi untuk masa depan tetapi sebagai fakta, maka harus dilakukan reformasi internal dan perbaikan sistem pendidikan secara berkesinambungan.

Studi pendahuluan menunjukkan, bahwa harapan tumbuhnya sifat kreaktif dan antisipatif para guru Fisika dalam praktik pembelajaran untuk memaksimalkan peranan siswa dewasa ini masih belum optimal. Patut diakui bahwa hasil-hasil pendidikan di Indonesia masih jauh dari harapan. Rendahnya kualitas sumber daya manusia Indonesia dalam persaingan global, terutama di bidang IPA dapat dilihat dari laporan Program for International Student Assessment (PISA). PISA 2009 yang berfokus pada literasi sains mengukuhkan siswa Shanghai China sebagai siswa dengan pencapaian tertinggi dalam literasi sains dengan skor rata-rata 575. Dari 74 negara peserta, siswa Indonesia mencapai posisi ke-66 dengan skor rata-rata 383 (Hayat dan Yusuf, 2011). Fakta lain juga dapat dilihat dari belum tercapainya angka kelulusan $100 \%$ ujian nasional selang tiga tahun terakhir.

Krathwohl, Bloom, dan Masia (1973) mengemukakan bahwa taksonomi domain terdiri atas cognitive domain, affective domain, dan psychomotor domain. Gagne et al (2005) mengemukakan ada lima kemampuan sebagai hasil belajar yaitu: (1) Verbal, (2) Intelectual, (3) Cognitive strategies, (4) Attitudes, dan (5) Motorskills. Hamalik (2008) mengemukakan bahwa bukti seseorang telah belajar ialah terjadi perubahan tingkah laku orang tersebut. Tingkah laku manusia terdiri dari sejumlah aspek yaitu: pengetahuan, pengertian, kebiasaan, keterampilan, apresiasi, emosional, hubungan sosial, jasmani, etis atau budi pekerti, dan sikap.

Anderson dan Krathwohl (2001) mengemukakan bahawa hasil belajar dalam ranah kognitif mencakup dua dimensi yaitu, dimensi pengetahuan dan dimensi proses kognitif yang dapat diklasifikasikan dalam kerangka taksonomi pendidikan. Anderson dan Krathwohl menetapkan empat jenis pengetahuan, yakni faktual, konseptual, prosedural, dan metakognitif. Sependapat dengan Bloom, Mulyasa (2009) mengemukakan bahwa hasil belajar merupakan prestasi belajar peserta didik secara keseluruhan yang menjadi indikator kompetensi dasar dan derajat perubahan perilaku. Hergenhahn dan Olson (2008) menunjukkan bahwa hasil belajar harus selalu diterjemahkan ke dalam perilaku atau tindakan yang dapat diamati. Salah satu faktor yang berpengaruh terhadap hasil belajar adalah cara guru mengemas pembelajaran.

Pengemasan pembelajaran dewasa ini tidak sejalan dengan hakikat orang belajar dan hakikat orang mengajar menurut pandangan kaum konstruktivis. Suparno (1997) mengemukakan bahwa mengajar berarti partisipasi dengan pebelajar dalam membentuk pengetahuan, membuat makna, mencari kejelasan, dan mengadakan justifikasi. Di lain pihak pembelajaran IPA yang hanya menekankan pada aspek produk seperti menghapal konsep-konsep, prinsip-prinsip atau rumus, tidak memberikan kesempatan kepada siswa terlibat aktif dalam proses-proses IPA. Bybee (2002) menegaskan bahwa belajar adalah interaksi ide-ide dan proses; pengetahuan baru dibangun berdasarkan pengetahuan awal; belajar meningkat ketika siswa menemukan makna, dan pembelajaran meningkat ketika siswa terlibat dalam diskusi tentang ide-ide dan terlibat dalam proses.

Tampaknya diperlukan transformasi pembelajaran, dari belajar secara menghafal ke belajar berpikir. Dari orientasi pada transfer pengetahuan ke pengembangan pengetahuan, keterampilan, dan watak". Salah satu pendekatan yang bisa digunakan dalam pembelajaran fisika, yang memberikan kesempatan kepada siswa untuk beraktifitas seperti ilmuwan adalah 
pendekatan inkuiri. Pendekatan inkuiri adalah suatu teknik instruksional yang dalam proses belajar-mengajar siswa dihadapkan dengan suatu masalah (Winatapura,1993). Langkah-langkah yang digunakan dalam penyajian materi dengan pendekatan inkuiri sebagai berikut: (a) fase berhadapan dengan masalah, (b) fase pengumpulan data pengujian, (c) fase pengumpulan data dalam eksperimen, (d) fase formulasi penjelasan, dan (e) fase penerapan konsep.

Dahar dan Liliasari (1986) memberikan definisi fungsional dari pendekatan inkuiri adalah pendidikan yang mempersiapkan situasi bagi anak untuk melakukan eksperimen sendiri. Bella et al (2010) menyatakan untuk domain belajar sains, mendefinisikan inkuiri sebagai proses mengajukan pertanyaan dan menyelidiki atau investigasi dengan data empiris. Lebih lanjut Taitelbaum et al (2008) mengemukakan bahwa pembelajaran sains menggunakan pendekatan inkuiri menyajikan tantangan baik bagi guru dan siswa. Pembelajaran dengan pendekatan inkuiri memerlukan keterlibatan dari siswa dalam kegiatan-kegiatan investigasi.

Pengajaran inkuiri merupakan pengajaran dengan para siswa mempelajari peristiwa-peristiwa ilmiah dengan pendekatan dan jiwa para ilmuwan (Harderet al, 2010 dan Dahar dan Liliasari, 1986). Kelebihan pendekatan inkuiri (Winatapura, 1993) antara lain adalah: (1) pengajaran menjadi lebih berpusat pada anak; (2) proses belajar melalui inkuiri dapat membentuk dan mengembangkan konsep diri pada diri siswa; (3) tingkat pengharapan bertambah; dan (4) pendekatan inkuiri dapat menghindari siswa dari cara-cara belajar dengan menghafal. Hasil penelitian yang dilakukan oleh Bilgin (2009) menunjukkan hasil yang signifikan setelah menggunakan model guided inquiry. Para siswa yang menggunakan model guided inquiry menunjukkan kinerja yang lebih baik dari siswa yang berada di kelas kontrol.

Kurikulum, proses pembelajaran, dan penilaian merupakan tiga dimensi dari sekian banyak dimensi yang sangat penting dalam pendidikan. Penilaian merupakan salah satu kegiatan yang dilakukan untuk mengukur dan menilai tingkat pencapaian kurikulum dan berhasil tidaknya proses pembelajaran. Penilaian atau assesment juga digunakan untuk mengetahui kekuatan dan kelemahan yang ada dalam proses pembelajaran, sehingga dapat dijadikan dasar untuk pengambilan keputusan, misalnya apakah proses pembelajaran sudah baik dan dapat dilanjutkan atau masih perlu perbaikan dan penyempurnaan. Oleh sebab itu, di samping kurikulum yang cocok dan proses pembelajaran yang benar perlu ada sistem penilaian yang baik dan terencana. Penilaian pembelajaran yang harus diterapkan pada kurikulum satuan pendidikan (KTSP) adalah penilaian berbasis kelas atau assesment berbasis kelas.

Surapranata dan Hatta (2004) mengemukakan bahwa asesmen berbasis kelas adalah penilaian yang dilakukan dalam proses pembelajaran untuk menetapkan tingkat pencapaian dan penguasaan peserta didik terhadap tujuan pendidikan yang telah ditetapkan dalam kurukulum. Penilaian berbasis kelas dapat dilakukan melalui berbagai cara di antaranya adalah penilain tertulis, penilaian afektif, penilaian psikomotor, penilaian lisan, penilaian jurnal, penilaian produk, penilaian proyek, penilaian diri, penilaian antar teman dan penilaian portofolio.

Melalui penilaian berbasis kelas, semua aspek hasil belajar seperti kognitif, afektif maupun psikomotor dapat dinilai secara utuh dalam pembelajaran. Di samping itu, dengan melakukan penilaian berbasis kelas guru akan memiliki informasi tentang siswanya dan memudahkan dalam membuat keputusan dalam menentukan hasil belajar siswa. Beberapa keuntungan lain yang diperoleh dari penggunaan penilaian berbasis kelas adalah: (1) umpan balik bagi siswa untuk mengetahui kemampuan dan kekurangannya, sehingga menimbulkan motivasi untuk memperbaiki hasil belajarnya; (2) memantau kemajuan dan mendiagnosis kemajuan belajar siswa sehingga memungkinkan dilakukan pengayaan dan remidiasi untuk memenuhi kebutuhan siswa sesuai dengan kemajuan dan kemampuannya; (3) memberikan masukan kepada guru untuk memperbaiki program pembelajaran di kelas; (4) memungkinkan siswa mencapai kompetensi yang telah ditentukan walaupun dengan ketepatan yang berbeda-beda, (5) dan memberikan informasi yang lebih komunikatif kepada masyarakat tentang efektivitas pendidikan sehingga meningkatkan partisipasinya. 
Rahmi (2009) mengemukakan bahwa selama ini penilaian didominasi dengan satu metode yaitu tes tertulis. Rustaman (diakses 2 Januari 2015) mengemukakan bahwa pembaharuan kurikulum akan lebih bermakna bila diikuti oleh perubahan praktik-praktik pembelajaran di kelas yang dengan sendirinya akan mengubah praktikpraktik penilaian. Selama ini praktik penilaian di kelas kurang menggunakan cara dan alat yang lebih bervariasi.

Berdasarkan uraian di atas model pembelajaran inkuiri memberikan peluang kepada siswa untuk lebih banyak terlibat dalam proses pembelajaran. Di samping itu, melalui model ini memberikan kesempatan kepada siswa untuk bekerja seperti ilmuwan dan memberikan kesempatan kepada siswa untuk mengaitkan pengetahuan awal dengan informasi baru, sehingga pembelajaran akan menjadi bermakna. Melalui model pembelajaran ini siswa diberikan kesempatan berlatih menggunakan keterampilan proses. Dengan menggunakan penilaian berbasis kelas, penilaian akan lebih bersifat menyeluruh dan berkesinambungan. Hal ini akan memungkinkan untuk meningkatkan motivasi belajar dan pada akhirnya akan bermuara pada hasil belajar siswa.

\section{METODE}

Penelitian ini dilakukan di SMP Negeri di Singaraja dengan menggunakan metode eksperimen semu. Sebagai variabel bebas adalah model pembelajaran dan jenis penilaian formatif, dan sebagai variabel tergantung adalah hasil belajar IPA. Model pembelajaran dibedakan menjadi dua, yaitu model pembelajaran inkuiri dan model pem- belajaran konvensional. Jenis penilaian formatif dibedakan menjadi dua, yaitu penilaian berbasis kelas (PBK) dan penilaian konvensional. Rancangan eksperimen yang digunakan adalah desain faktorial $2 \times 2$. Populasi penelitian ini adalah semua siswa kelas VII SMP Negeri di Singaraja pada semester ganjil tahun ajaran 2015/2016 sebanyak 2.398 siswa. Pengambilan sampel dilakukan dengan teknik multi stage dengan jumlah sampel 120 siswa. Instrumen untuk mengukur hasil belajar IPA digunakan tes bentuk pilihan ganda, yang terdiri atas 35 butir dengan nilai reliabilitas sebesar 0,8770. Teknik analisis data menggunakan anava dua jalur (Candiasa 2011) dan sebelumnya dilakukan uji prasyarat uji normalitas dan uji homogenitas varians. Kriteria pengujian, $\mathrm{H}_{0}$ ditolak jika angka signifikansi lebih kecil dari 0,05. Jika terjadi interaksi akan dilakukan uji lanjut dengan uji-t satu ekor. Kriteria pengujian, $\mathrm{H}_{0}$ ditolak jika angka signifikansi lebih kecil dari 0,05.

\section{HASIL DAN PEMBAHASAN Hasil Penelitian}

Hasil analisis ukuran sentral, ukuran sebaran data, varian, nilai minimum, dan nilai maksimum memberikan hasil seperti ditunjukkan pada Tabel 1.

Pengujian normalitas sebaran data dimaksudkan untuk meyakinkan bahwa sampel benarbenar berasal dari populasi yang berdistribusi normal, sehingga uji hipotesis dapat dilakukan. Hasil analisis uji normalitas sebaran data disajikan pada Tabel 2.

Pengujian homogenitas varian bertujuan untuk meyakinkan bahwa jika diperoleh perbe-

Tabel 1. Rekapitulasi Hasil Analisis Data Hasil Belajar IPA

\begin{tabular}{|c|c|c|c|c|c|c|c|c|}
\hline $\begin{array}{l}\text { MP dan } \\
\text { JPF } \\
\text { tik }\end{array}$ & Inkuiri & $\begin{array}{c}\text { Konven- } \\
\text { sional }\end{array}$ & PBK & PK & $\begin{array}{c}\text { PBK } \\
\text { Inkuiri }\end{array}$ & $\begin{array}{c}\text { PK } \\
\text { Inkuiri }\end{array}$ & $\begin{array}{c}\text { PBK } \\
\text { Konven- } \\
\text { sional }\end{array}$ & $\begin{array}{c}\text { PK } \\
\text { Konven- } \\
\text { sional }\end{array}$ \\
\hline Mean & 73,85 & 70,92 & 73,50 & 71,27 & 78,50 & 69,20 & 68,50 & 73,33 \\
\hline $\begin{array}{l}\text { Standar } \\
\text { Deviasi }\end{array}$ & 7,7674 & 6,4211 & 7,5566 & 6,8044 & 5,0633 & 7,2369 & 6,2298 & 5,7436 \\
\hline Varians & 60,333 & 41,230 & 57,102 & 46,301 & 25,638 & 52,372 & 38,810 & 32,989 \\
\hline $\begin{array}{l}\text { Skor } \\
\text { Minimum }\end{array}$ & 51 & 54 & 54 & 51 & 69 & 51 & 54 & 60 \\
\hline $\begin{array}{l}\text { Skor } \\
\text { Mak- } \\
\text { simum }\end{array}$ & 88 & 86 & 88 & 86 & 88 & 83 & 80 & 86 \\
\hline
\end{tabular}


Tabel 2. Rekapitulasi Hasil Uji Normalitas Sebaran Data

\begin{tabular}{lcccc}
\hline \multicolumn{1}{c}{ Kelompok Sampel } & $\begin{array}{c}\text { Jumlah } \\
\text { Sampel }\end{array}$ & Sig & $\boldsymbol{\alpha}$ & Kesimpulan \\
\hline Model Pembelajaran Inkuiri $\left(\mathrm{A}_{1}\right)$ & 60 & 0,080 & 0,05 & Normal \\
Model Pembelajaran Konvensional $\left(\mathrm{A}_{2}\right)$ & 60 & 0,378 & 0,05 & Normal \\
PBK $\left(\mathrm{B}_{1}\right)$ & 60 & 0,214 & 0,05 & Normal \\
Penilaian Konvensional $\left(\mathrm{B}_{2}\right)$ & 60 & 0,414 & 0,05 & Normal \\
$\mathrm{A}_{1} \mathrm{~B}_{1}$ & 30 & 0,227 & 0,05 & Normal \\
$\mathrm{A}_{1} \mathrm{~B}_{2}$ & 30 & 0,807 & 0,05 & Normal \\
$\mathrm{A}_{2} \mathrm{~B}_{1}$ & 30 & 0,531 & 0,05 & Normal \\
$\mathrm{A}_{2} \mathrm{~B}_{2}$ & 30 & 0,730 & 0,05 & Normal \\
\hline
\end{tabular}

Tabel 4. Hasil ANAVA Dua Jalur Untuk Hasil Belajar IPA

\begin{tabular}{|c|c|c|c|c|c|c|c|c|}
\hline Source & $\begin{array}{c}\text { Type III Sum } \\
\text { of Squares }\end{array}$ & df & $\begin{array}{l}\text { Mean } \\
\text { Square }\end{array}$ & $\mathrm{F}$ & Sig. & $\begin{array}{c}\text { Partial Eta } \\
\text { Squared }\end{array}$ & $\begin{array}{l}\text { Noncent. } \\
\text { Parameter }\end{array}$ & $\begin{array}{l}\text { Observed } \\
\text { Power }^{\mathrm{b}}\end{array}$ \\
\hline $\begin{array}{l}\text { Corrected } \\
\text { Model }\end{array}$ & $1.905,900^{\mathrm{a}}$ & 3 & 635,300 & 16,963 & 0,000 & 0,305 & 50,889 & 1,000 \\
\hline Intercept & $628.721,633$ & 1 & $628.721,63$ & $16.787,264$ & 0,000 & 0,993 & $16.787,264$ & 1,000 \\
\hline A & 258,133 & 1 & 258,133 & 6,892 & 0,010 & 0,056 & 6,892 & 0,740 \\
\hline B & 149,633 & 1 & 149,633 & 3,995 & 0,048 & 0,033 & 3,995 & 0,509 \\
\hline$A * B$ & $1.498,133$ & 1 & $1.498,133$ & 40,001 & 0,000 & 0,256 & 40,001 & 1,000 \\
\hline Error & $4.344,467$ & 116 & 37,452 & & & & & \\
\hline Total & $634.972,000$ & 120 & & & & & & \\
\hline $\begin{array}{l}\text { Corrected } \\
\text { Total }\end{array}$ & $6.250,367$ & 119 & & & & & & \\
\hline
\end{tabular}

daan dari hasil uji ANAVA, perbedaan yang diperoleh benar-benar berasal dari perbedaan antar kelompok, bukan disebabkan oleh perbedaan yang terjadi di dalam kelompok. Hasil analisis uji homogenitas varian disajikan pada Tabel 3.

Tabel 3. Rekapitulasi Hasil Uji Homogenitas Varian

\begin{tabular}{lccc}
\hline \multicolumn{1}{c}{ Kelompok Data } & Sig & $\boldsymbol{\alpha}$ & Kesimpulan \\
\hline $\mathrm{A}_{1}$ dengan $\mathrm{A}_{2}$ & 0,085 & 0,05 & Homogen \\
$\mathrm{B}_{1}$ dengan $\mathrm{B}_{2}$ & 0,294 & 0,05 & Homogen \\
$\mathrm{A}_{1} \mathrm{~B}_{1}, \mathrm{~A}_{1} \mathrm{~B}_{2}, \mathrm{~A}_{2} \mathrm{~B}_{1}$, & 0,472 & 0,05 & Homogen \\
dan $\mathrm{A}_{2} \mathrm{~B}_{2}$ & & \\
\hline
\end{tabular}

Hasil analisis data dengan ANAVA dua jalur dalam penelitian ini dapat diikhtisarkan seperti pada Tabel 4.

Berdasarkan hasil analisis yang diiktisarkan pada Tabel 4 dapat dirumuskan hasil uji hipotesis sebagai berikut.

Hasil analisis yang menunjukkan bahwa nilai $\mathrm{F}_{\text {hitung }}=6,892$ untuk taraf signifikansi 0,05. $\mathrm{Hal}$ itu berarti bahwa $\mathrm{H}_{0}$ ditolak dan $\mathrm{H}_{1}$ diterima, sehingga dapat disimpulkan terdapat perbedaan secara signifikan hasil belajar IPA antara siswa yang mengikuti model pembelajaran inkuiri dan siswa yang mengikuti model pembelajaran konvensional. Karena terdapat perbedaan hasil belajar IPA antara kelompok siswa yang mengikuti model pembelajaran inkuiri dan yang mengikuti model pembelajaran konvensional, maka lebih lanjut dibandingkan nilai rata-rata hasil belajar IPA pada kelompok manakah yang lebih tinggi.

Hasil analisis menunjukkan, siswa yang mengikuti pembelajaran dengan model pembelajaran inkuiri (kelompok $A_{1}$ ) memiliki nilai ratarata hasil belajar IPA sebesar 73,85, sedangkan kelompok siswa yang mengikuti pembelajaran dengan model pembelajaran konvensional (kelompok $\mathrm{A}_{2}$ ) memiliki nilai hasil belajar IPA sebesar 70,92. Jadi dapat disimpulkan, hasil belajar IPA siswa yang mengikuti pembelajaran dengan model pembelajaran inkuiri lebih tinggi daripada hasil belajar IPA siswa yang mengikuti pembelajaran dengan model pembelajaran konvensional.

Selanjutnya, hasil analisis yang menunjukkan bahwa nilai $\mathrm{F}_{\text {hitung }}=3,995$ untuk taraf signifikansi 0,05 . Hal itu berarti bahwa $\mathrm{H}_{0}$ ditolak dan $\mathrm{H}_{1}$ diterima, sehingga dapat disimpulkan terdapat perbedaan secara signifikan hasil belajar IPA antara siswa yang mengikuti penilaian berbasis kelas dan siswa yang mengikuti penilaian kon- 
vensional. Karena terdapat perbedaan hasil belajar IPA antara kelompok siswa yang mengikuti penilaian berbasis kelasdan yang mengikuti penilaian konvensional, maka lebih lanjut dibandingkan nilai rata-rata hasil belajar IPA pada kelompok manakah yang lebih tinggi.

Hasil analisis menunjukkan bahwa siswa yang mengikuti penilaian berbasis kelas (kelompok $B_{1}$ ) memiliki nilai rata-rata hasil belajar IPA sebesar 73,50, sedangkan kelompok siswa yang mengikuti penilaian konvensional (kelompok $\mathrm{B}_{2}$ ) memiliki nilai hasil belajar IPA sebesar 71,27. Jadi dapat disimpulkan, hasil belajar IPA siswa yang mengikuti penilaian berbasis kelas lebih tinggi daripada hasil belajar IPA siswa yang mengikuti penilaian konvensional.

Hasil analisis yang menunjukkan bahwa nilai $\mathrm{F}_{\text {hitung }}=40,001$, dan angka signifikan yang ditunjukkan $=0,000<$ dari $\alpha=0,05$. Hal itu berarti bahwa $\mathrm{H}_{0}$ ditolak dan $\mathrm{H}_{1}$ diterima, sehingga dapat disimpulkan terdapat pengaruh interaksi secara signifikan antara model pembelajaran dan jenis penilaian formatif terhadap hasil belajar IPA siswa.

Interaksi antara model pembelajaran dengan jenis penilaian formatif dalam pengaruhnya terhadap hasil belajar IPA dapat divisualisasikan secara grafis seperti tampak pada Gambar 1.

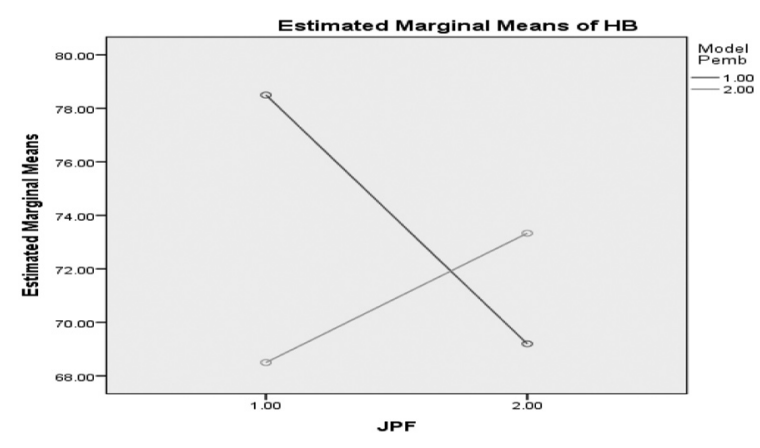

\section{Gambar 1. Visualisasi Interaksi antara Model Pembelajaran dan Jenis}

\section{Penilaian Formatif dalam Pengaruhnya ter- hadap Hasil Belajar IPA}

Mengingat hipotesis interaksi teruji kebenarannya secara signifikan, perlu dilakukan uji lanjut atau uji hipotesis simple effect.

1) $t_{h}\left(A_{1} B_{1}-A_{1} B_{2}\right)$

Hasil analisis pengujian diperoleh nilai $t_{\text {hitung }}=$ $3,725>t_{\text {tabel( }(0,05 ; 66)}=1,660$, sehingga $\mathrm{H}_{0}$ ditolak atau $\mathrm{H}_{1}$ diterima, maka dapat disimpulkan bahwa untuk siswa yang, siswa yang mengikuti model pembelajaran inkuiri, siswa yang diberi PBK mempunyai hasil belajar IPA lebih tinggi daripada yang diberi penilaian konvensional.

2) $t_{h}\left(A_{1} B_{1}-A_{2} B_{1}\right)$

Hasil analisis pengujian diperoleh nilai $t_{\text {hitung }}=$ $4,005>t_{\text {tabel }(0,05 ; 66)}=1,660$,sehingga $\mathrm{H}_{0}$ ditolak atau $\mathrm{H}_{1}$ diterima, maka dapat disimpulkan bahwa untuk siswa yang diberi PBK, siswa yang mengikuti model pembelajaran inkuiri mempunyai hasil belajar IPA lebih tinggi daripada yang mengikuti model pembelajaran konvensional.

3) $t_{h}\left(A_{1} B_{2}-A_{2} B_{2}\right)$

Hasil analisis pengujian diperoleh nilai $t_{\text {hitung }}=$ $4,130>t_{\text {tabel( }(0,05 ; 66)}=1,660$, sehingga $\mathrm{H}_{0}$ ditolak atau $\mathrm{H}_{1}$ diterima, maka dapat disimpulkan bahwa untuk siswa yang diberi penilaian konvensional, siswa yang mengikuti model pembelajaran inkuiri mempunyai hasil belajar IPA lebih rendah daripada yang mengikuti model pembelajaran konvensional.

4) $t_{h}\left(A_{2} B_{1}-A_{2} B_{2}\right)$

Hasil analisis pengujian diperoleh nilai $t_{\text {hitung }}=$ $4,830>t_{\text {tabel }(0,05 ; 66)}=1,660$,sehingga $\mathrm{H}_{0}$ ditolak atau $\mathrm{H}_{1}$ diterima, maka dapat disimpulkan bahwa untuk siswa yang mengikuti model pembelajaran konvensional, siswa yang diberi PBK mempunyai hasil belajar IPA lebih rendah daripada yang diberi penilaian konvensional.

\section{Pembahasan}

Berdasarkan hasil analisis data telah terbukti bahwa hasil belajar IPA siswa yang mengikuti model pembelajaran inkuiri lebih tinggi daripada yang mengikuti model pembelajaran konvensional. Hal ini disebabkan pembelajaran IPA dengan model pembelajaran inkuiri memberikan iklim yang subur bagi terciptanya kondisi belajar yang demokratis. Keterlibatan siswa dalam kegiatan-kegiatan inkuiri akan memberikan kesempatan kepada siswa untuk memupuk rasa tanggung jawab, mengembangkan kreativitas, memupuk kejujuran, memupuk sikap kritis, dan menumbuhkembangkan rasa percaya diri. Dengan dimilikinya rasa tanggung jawab yang tinggi, kreativitas serta adanya rasa percaya diri pada 
diri siswa, pada akhirnya akan memberi dampak yang positip terhadap hasil belajar siswa. Di samping itu keterlibatan siswa dalam kegiatan inkuiri akan memberikan dampak pengiring terhadap mengembangan sikap ilmiah, tanggung jawab, kerja sama, dan kreativitas siswa, hal ini akan berpengaruh dalam pembentukan karakter.

Hasil penelitian ini mendukung teori tentang model pembelajaran inkuiri menurut Trowbridgedan Sund (1990), model pembelajaran inkuiri memberikan kebaikan pembelajaran menjadi lebih berpusat pada anak (Instruction becomes student-centered). Model pembelajaran inkuiri memberikan kesempatan kepada siswa untuk mengaitkan pengetahuan awal siswa dengan materi yang akan dipelajari sehingga pembelajaran menjadi lebih bermakna. Model pembelajaran konvensional kurang memberikan kesempatan kepada siswa untuk terlibat aktif dalam pembelajaran sehingga mengakibatkan pembelajaran kurang bermakna.

Hasil penelitian ini mendukung hasil penelitian yang dilakukan oleh Putra, hasil penelitian menunjukkan siswa yang dipasilitasi dengan model pembelajaran inkuiri memunyai nilai pemahaman konsep IPA lebih tinggi daripada yang dipasilitasi dengan model pembelajaran konvensional (diakses 20 Februari 2015). Hasil penelitian ini juga mendukung hasil penelitian yang dilakukan oleh Bilgin. Hasil penelitian Bilgin menunjukkan kelompok siswa yang menggunakan model guided inquiry menunjukkan kinerja yang lebih baik dari siswa yang berada di kelas kontrol (diakses 7 April 2015). Dari paparan di atas dapat disimpulkan hasil belajar IPA siswa yang mengikuti model pembelajaran inkuiri lebih tinggi daripada yang mengikuti model pembelajaran konvensional, setelah mengontrol pengetahuan awal siswa.

Hasil pengujian secara statistik membuktikan bahwa hasil belajar IPA siswa yang diberi PBK lebih tinggi daripada yang diberi penilaian konvensional. Hal ini disebabkan penilaian berbasis kelas (PBK) berguna sebagai: (1) umpan balik bagi siswa untuk mengetahui kemampuan dan kekurangannya, sehingga menimbulkan motivasi untuk memperbaiki hasil belajarnya; (2) memantau kemajuan dan mendiagnosis kemajuan belajar siswa sehingga memungkinkan dilaku- kan pengayaan dan remidiasi untuk memenuhi kebutuhan siswa sesuai dengan kemajuan dan kemampuannya; dan (3) memberikan masukan kepada guru untuk memperbaiki program pembelajaran di kelas. Penilaian konvensional lebih difokuskan pada aspek kognitif dengan kata lain kurang menyeluruh, kurang berkesinambungan hal ini kurang mampu meningkatkan hasil belajar siswa.

Hasil penelitian ini mendukung kajian teori mengenai penilaian berbasis kelas (Surapranata dan Hatta, 2004), yaitu bahwa prinsip penilaian berbasis kelas adalah valid, adil, terbuka, berkesinambungan, bermanfaat, menyeluruh, dan mendidik, yang dapat memotivasi siswa dalam pembelajaran. Jika siswa termotivasi dalam pembelajaran, akan berpengaruh terhadap hasil belajar siswa. Hasil penelitian ini mendukung hasil penelitian yang dilakukan oleh Balik (diakses 29 Maret 2015), menunjukkan implementasi asesmen autentik (PBK) dalam pembelajaran matematika dapat meningkatkan prestasi belajar matematika dan motivasi peserta didik.

Hasil pengujian secara statistik membuktikan bahwa terdapat pengaruh interaksi antara model pembelajaran dan jenis penilaian formatif terhadap hasil belajar IPA siswa. Bella et al (2010) mengemukakan bahwa belajar inkuiri secara kolaboratif merupakan salah satu usaha yang paling menantang dan menarik untuk sekolah saat ini. Ini bertujuan untuk membawa budaya baru dan menjanjikan belajar mengajar dalam kelas dan siswa dalam kelompok terlibat dalam self regulated kegiatan pembelajaran didukung oleh guru. Diharapkan cara belajar ini memupuk motivasi dan minat siswa dalam sains, mereka belajar untuk melakukan langkah-langkah penyelidikan serupa dengan para ilmuwan dan mereka mendapatkan pengetahuan tentang proses sains.

Di sisi lain model pembelajaran konvensional cendrung dimulai dengan guru menyajikan materi pelajaran, dilanjutkan dengan memberikan contoh soal. Model pembelajaran ini lebih berpusat pada guru (teacher realitas), dalam proses pembelajaran guru memunyai peranan yang sangat penting. Kegiatan pembelajaran yang berpusat pada guru menekankan pentingnya aktivitas guru dalam proses pembelajaran. Siswa berperan sebagai penerima informasi, dengan kata lain 
siswa bersifat pasif dalam proses pembelajaran. Model pembelajaran ini kurang memberikan kesempatan kepada siswa untuk mengkonstruksi pengetahuannya sendiri sehingga pembelajaran menjadi kurang bermakna.

Penilaian hasil belajar oleh pendidik dilakukan secara berkesinambungan untuk memantau proses, kemajuan, dan perbaikan hasil dalam bentuk penilaian harian, penilaian tengah semester, penilaian akhir semester, dan penilaian kenaikan kelas. Penilaian hasil belajar tingkat kelas dapat dilakukan dengan penilaian berbasis kelas (PBK). Stiggins dan Chappuis, menyatakan penilaian kelas (Classroom Assessment) dapat digunakan untuk mendorong siswa lebih produktif lebih percaya diri. Stiggins dan Chappuis (diakses 29 Maret 2015) mengemukakan bahwa ada tiga cara yang bisa digunakan untuk memotivasi siswa agar selalu terlibat dalam pembelajaran yaitu: keterlibatan siswadalam penilaian proses, pencatatan dan komunikasi.

Keterlibatan siswa dalam penilaian proses, siswa diajak untuk berperan dalam menentukan kriteria dimana pekerjaan mereka akan dinilai. Mereka belajar untuk menerapkan kriteria, mengidentifikasi kekuatan dan kelemahan mereka sendiri. Hal ini akan membangun kepercayaan dan keyakinan siswa. Siswa terlibat dalam pencatatan (record) mendorong peserta didik untuk memantau perbaikan kinerja mereka dari waktu ke waktu melalui self-assessment. Misalnya, siswa membangun portofolio bukti kesuksesan mereka dari waktu ke waktu, mereka dapat merefleksikan perubahan yang mereka lihat. Ketika mereka memetakan kemajuan, mereka memperoleh rasa kontrol atas pembelajaran mereka sendiri. Ini bisa menjadi pembangun kepercayaan diri yang kuat. Siswa terlibat dalam komunikasi, mengajak untuk berbagi dengan orang lain misalnya dengan guru dan orang tua.

Ketika siswa dipersiapkan dengan baik melalui menceritakan kisah kesuksesan atau kegagalan mereka sendiri, mereka mengalami perubahan mendasar dalam internal mereka, rasa tanggung jawab atas keberhasilan itu. Siswa merasa bangga ketika mereka memiliki kisah yang positif dan kemudian menimbulkan komitmen untuk belajar lebih lanjut. Bagi siswa yang kurang berhasil, merasa punya tanggung jawab besar untuk bekerja keras dan mendorong mereka bekerja lebih produktif. Di sisi lain penilaian konvensional hanya menekankan hasil dan hasil belajar hanya difokuskan pada aspek kognitif. Test menjadi cara penilaian yang dominan, penilaian hanya dilakukan oleh guru, dan dilaksanakan setelah satu pokok bahasan diajarkan yang diistilahkan dengan penilaian blok.

Berdasarkan uraian di atas temuan penelitian ini disebabkan dalam pembelajaran sains atau IPA, model pembelajaran inkuiri lebih diuntungkan dengan penilaian berbasis kelas. Dalam konteks ini variasi penilaian sangat berpengaruh terhadap hasil belajar. Variasi penilaian ini lebih besar peluangnya diterapkan pada model pembelajaran inkuiri. Di sisi lain bila dikaitkan dengan pembelajaran sains atau IPA, model pembelajaran konvensional lebih difasilitasi atau lebih diuntungkan dengan penilaian konvensional. Temuan ini memberikan informasi bahwa data penelitian ini mendukung kebenaran hipotesis yang diajukan. Hasil penelitian ini juga sejalan dengan hasil penelitian oleh Akinoglu (diakses 7 April 2015) penelitian tentang Penilaian Kelas Berbasis Inkuiri diimplementasiakan di Pendidikan Sains menemukan bahwa penilaian kelas meningkatkan nilai dalam ujian.

Hasil penelitian menunjukkan, untuk siswa yang diberi PBK, siswa yang mengikuti model pembelajaran inkuiri memunyai hasil belajar IPA lebih tinggi daripada yang mengikuti model pembelajaran konvensional. Hal ini disebabkan model pembelajaran inkuiri lebih memberikan kesempatan kepada siswa melakukan investigasi menggunakan keterampilan proses dan mengembangkan sikap ilmiah. Di sisi lain PBK dilakukan secara menyeluruh dan berkesinambungan. Bila dikaitkan dengan pembelajaran sains atau IPA, penilaian berbasis kelas lebih diuntungkan dalam model pembelajaran inkuiri. Dalam konteks ini variasi penilaian sangat berpengaruh terhadap hasil belajar. Variasi penilaian ini lebih besar peluangnya diterapkan pada model pembelajaran inkuiri.

Hasil penelitian juga menunjukkan bahwa untuk siswa yang mengikuti model pembelajarn inkuiri, siswa yang diberi PBK memunyai hasil belajar IPA lebih tinggi daripada yang diberi penilaian konvensional. Hal ini disebabkan jika 
dikaitkan dengan hakekat IPA yakni IPA sebagai produk dan IPA sebagai proses, model pembelajaran inkuiri lebih diuntungkan dalam PBK. Dalam konteks ini variasi pengalaman belajar siswa yang difasilitasi melalui model pembelajaran sangat berpengaruh terhadap hasil belajar. Hasil penelitian juga menunjukkan bahwa siswa yang diberi penilaian konvensional, siswa yang mengikuti model pembelajaran inkuiri memunyai hasil belajar IPA lebih rendah daripada yang mengikuti model pembelajaran konvensional.

Bila dikaitkan dengan pembelajaran sains, penilaian konvensional lebih diuntungkan dalam model pembelajaran konvensional, karena dalam pembelajaran dengan menggunakan model pembelajaran konvensional pembelajaran lebih berpusat pada guru dan bersifat transfer informasi dan berorientasi pada hasil. Siswa dalam kelompok ini akan lebih merasa nyaman diberikan penjelasan materi oleh guru dengan cara mencatat bahan pelajaran tanpa ada interaksi yang aktif dari guru maupun dari siswa itu sendiri. Kebiasaan siswa pasif, jarang berinteraksi di kelas, sesuai dengan ciri dari model pembelajaran konvensional, aktivitas siswa akan terasa kurang karena siswa mendengarkan penjelasan dari guru sambil mencatat.

Hasil penelitian juga menunjukkan bahwa untuk siswa yang mengikuti model pembelajarn konvensional, siswa yang diberi PBK memunyai hasil belajar IPA lebih rendah daripada yang diberi penilaian konvensional. Hal ini disebabkan model pembelajaran konvensional, guru yang lebih dominan dalam proses pembelajar. Interaksi dalam pembelajaran kurang multiarah, pengalaman belajar siswa mencatan materi yang diajarkan oleh guru. Siswa sudah terpola bersifat pasif dalam pembelajaran, sehingga mereka merasa lebih nyaman dengan model pembelajaran konvensional. Berdasarkan karakteristik dari penilaian konvensional, penilaian konvensional hanya menekankan hasil dan lebih difokuskan hasil belajar pada aspek kognitif. Test menjadi cara penilaian yang dominan, penilaian hanya dilakukan oleh guru, dan dilaksanakan setelah satu pokok bahasan diajarkan yang diistilahkan dengan penilaian blok. Siswa sudah terbiasa dengan penilaian konvensional sehingga mereka merasa lebih nyaman diberikan penilaian konvensional.

\section{PENUTUP \\ Simpulan}

1. Terdapat perbedaan hasil belajar IPA antara siswa yang mengikuti model pembelajaran inkuiri dan yang mengikuti model pembelajaran konvensional

2. Terdapat perbedaan hasil belajar IPA antara siswa yang diberi penilaian berbasis kelas (PBK) dan yang diberi penilaian konvensional.

3. Terdapat pengaruh interaksi antara model pembelajaran dan jenis penilaian formatif terhadap hasil belajar IPA siswa.

\section{Saran}

Mengingat bahwa model pembelajaran inkuiri memiliki keunggulan komparatif terhadap model pembelajaran konvensional, maka kepada para guru IPA di SMP disarankan agar mencoba menerapkan model tersebut dalam kegiatan pembelajaran IPA di sekolah, dengan terlebih dahulu memahami hakekat pandangan konstruktivisme dalam belajar mengajar, karena model pembelajaran inkuiri berpijak pada pandangan konstruktivisme. Penilaian berbasis kelas juga memiliki keunggulan komparatif terhadap penilaian konvensional, maka kepada para guru IPA di SMP disarankan agar mencoba mengimplementasikan jenis penilaian tersebut untuk menilai kompetensi atau kemampuan siswa, dengan terlebih dahulu memahami prinsip-prinsip penilaian berbasis kelas.

Hasil penelitian ini juga menunjukkan terdapat pengaruh interaksi antara model pembelajaran dan jenis penilaian formatif terhadap hasil belajar IPA siswa. Setelah mengontrol pengetahuan awal siswa, untuk siswa yang mengikuti model pembelajarn inkuiri, siswa yang diberi PBK memunyai hasil belajar lebih tinggi daripada yang diberi penilaian konvensional, maka kepada para guru IPA di SMP disarankan jika dalam pembelajaran menerapkan model pembelajaran inkuiri agar menggunakan penilaian berbasis kelas, sedangkan jika mengimplementasikan model pembelajaran konvensional maka gunakan penilaian konvensional. 


\section{UCAPAN TERIMA KASIH}

Pada kesempatan ini, penulis mengucapkan banyak terima kasih kepada semua pihak yang telah membantu dalam penelitian dan penulisan artikel ini terutama Prof. Dr. I Wayan Suastra, M.Pd yang telah banyak membantu penulis sehingga penulis dapat menyelesaikan artikel ini.

\section{DAFTARPUSTAKA}

Akinoglu, Orhan. 2008. "Assessment of The Inquiry-Based Project Implementation Process in Science Education Upon Students' Points of Views." International Journal of Instruction, Vol.1(1), pp: 1-12. Error! Hyperlink reference not valid. (diakses 7 April 2015).

Anderson, L. W., \& David R. K. 2001. A Taxonomy for Learning Teaching Assessing. New York: Longman.

Balik, I Wayan. Pengaruh Implementasi Asesmen Autentik terhadap Prestasi Belajar Matematika dan Motivasi Berprestasi. Error! Hyperlink reference not valid. (diakses 29 Maret 2015).

Bybee, R. W. 2002. Learning Science and the Science of Learning. New York: Kirby Lithographic Company.

Bella, T, Urhahneb, D., Schanzec, S. \& Ploetznerd, R. 2010."Collaborative Inquiry Learning: Models, Tools, and Challenges." International Journal of Science Education, Vol. 32 (3).

Bilgin, I. 2009. "The Effects of Guided Inquiry Instruction Incorporating a Cooperative Learning Approach on University Students' Achievement of Acid And Bases Concepts and Attitude" Toward Guided Inquiry Instruction. http://www.academicjournals. org/sre (diakses 7 April 2015).

Buchori, M. 2001. Pendidikan Antisipatoris. Yogyakarta: Kanisius.
Candiasa, I Made. 2011. Statistik Multivariat Disertai Aplikasi SPSS. Singaraja: Undiksha Press.

Dahar, R. W. dan Liliasari.1986. Interaksi Belajar Mengajar IPA. Jakarta: Universitas Terbuka.

Faure, E., Herrera F., Kaddoura, A. R., Lopes H., Petrovsky, A. V., Rahnema, M., \&Ward F. C. 1982.Learning to Be the World Education Today and Tomorrow. Paris: Offset Aubin.

Hayat, B. dan Yusuf, S. 2011. Mutu Pendidikan. Jakarta: Bumi Aksara.

Hamalik, Oemar. 2008. Proses Belajar Mengajar. Jakarta: PT Bumi Aksara.

Harder, R. J. et al. 2010. Teaching Strategies A Guide To Effective Instruction.Boston: Wadsworth.

Hergenhahn, B. R. \& Olson, M.O. 2008. Teori Belajar, terjemahan Wibowo, B. S. Jakarta: Kencana.

Krathwohl, D. R., Bloom, B. S., \& Masia, B. B. 1973. Taxonomy of Educational Objectives: The Classificationof Educational Goals. Handbook II: The Affective Domain. New York: David McKay

Mulyasa, H. E. 2009. Implementasi Kurikulum Tingkat Satuan Pendidikan. Jakarta: PT Bumi Aksara.

Putra, Ida Bagus Soma. "Pengaruh Model Pembelajaran Inkuiri dan Motivasi Belajar Terhadap Pemahaman Konsep IPA". http:// pasca.undiksha.ac.id/e-journal/index.php/ jurnal_tp/article/view/293 (diakses 20 Februari 2015).

Rahmi, Taufina. "Authentic Assessment dalam Pembelajaran Bahasa Indonesia di Kelas Rendah SD." Jurnal Ilmiah Ilmu Pendidikan, Volume IX, No.1, April 2009: 113- 
120. http://ejournal.unp.ac.id/index.php/ pedagogi/article/download/123/(diakses 29 Maret 2013).

Rustaman, Nuryani Y. Penilaian Berbasis Kelas. http://file.upi.edu/Direktori/SPS/PRODI. PENDIDIKAN_IPA/195012311979032NURYANI_RUSTAMAN/PENILAIAN_BERBASIS_KELAS. (diakses 2 Januari 2013).

Stiggins, Rick dan Jan Chappuis. Using StudentInvolved Classroom Assessment to Close Achievement Gaps. Error! Hyperlink reference not valid. (diakses 29 Maret 2013).

Suparno, P. 1997. Filsafat Konstruktivisme dalam Pendidikan. Yogyakarta: Kanisius.

Surapranata, Sumarna dan Muhammad Hatta. 2004. Penilaian Portofolio. Bandung: PT Remaja Rosdakarya.
Taitelbaum, D., Naaman, R. M., Carmeli, M. \& Hofstein, A.2008. "Evidence for Teachers' Change While Participating in a ContinuousProfessional Development Programme and Implementing the InquiryApproach in the Chemistry Laboratory." International Journal of Science Education, Vol. 30, No. 5, hlm. 593-617. http://www.informaworld. $\mathrm{com} / \mathrm{smpp} /$ title $\sim$ content $=\mathrm{t} 713737283$ (diakses 24 April 2011).

Trowbridge, Leslie W., dan Robert B. Sund. 1990.Becoming a Secondary School Science Teacher. Ohio: Merrill Publishing Company.

Winatapura, U. S. 1993. Strategi Belajar Mengajar IPA. Jakarta: Universitas Terbuka Depdikbud. 